\title{
Effect of supplemental lipids on in vitro fermentation capacity of rumen contents from cows receiving a diet with or without oil
}

\author{
JF Ottou 1,2, M Doreau 1 \\ 1 INRA, Laboratoire Sous-Nutrition des Ruminants, Theix, \\ 63122 Saint-Genès-Champanelle, France \\ 2 IRZV, BP 1457 Yaoundé, Cameroon
}

The aim of this study was to define conditions for maximum effects of oil on rumen microbes in batch cultures.

Rumen contents were collected from 2 cows fed $8 \mathrm{~kg}$ DM of a maize silage and concentrate diet in ratio $80: 20$ (DM basis) with no (C) or $0.6 \mathrm{~kg}$ rapeseed oil (RO)/cow/d (T). Fermentations were done in $1 \mathrm{I}$ flasks with rumen juice and rumen solid contents (1:1) according to Jouany and Thivend (1986). Soluble nitrogen and sulphur were provided by a urea $/ \mathrm{Na}_{2} \mathrm{SO}_{4}$ solution instead of $\left(\mathrm{NH}_{4}\right)_{2} \mathrm{SO}_{4}$ when starch was substituted by cellulose as energy substrate. Prior to incubation, RO and rapeseed oil fatty acids (RA) were added to flasks with rumen contents $C$ and $T$ at amounts of $0,6,9$ and $12 \mathrm{gRO}$ and $6 \mathrm{~g}$ RA with $13 \mathrm{~g}(\mathrm{DM})$ cellulose; and 0,6 and $9 \mathrm{~g}$ RO with $13 \mathrm{~g}$ (DM) wheat starch. Total gas production after $24 \mathrm{~h}$ for cellulose and $6 \mathrm{~h}$ for wheat starch was measured as a criterion for microbial activity. Data were analysed using an analysis of variance model including the effect of both dietary and supplementary RO and their interaction. Means were separated by Duncan's multiple range test.

Dietary RO as well as its addition in the flasks decreased $(P<0.001)$ gas production in the presence of cellulose (table I). Their interaction was not significant. Differences in gas production between diets $C$ and $T$ were higher with starch as substrate: $750,530,540 \mathrm{ml}$ after $6 \mathrm{~h}$, than with cellulose; $343,380,294 \mathrm{ml}$ after $24 \mathrm{~h}$ when 0,6 and $9 \mathrm{~g}$ RO were supplied to incubation flasks, respectively. Total gas production (mean of diets $\mathrm{C}$ and $\mathrm{T}$ ) was more depressed by $6 \mathrm{~g}$ RA than by $6 \mathrm{~g} \mathrm{RO}$ and control when introduced directly into batch cultures containing cellulose: 1640 , 1823 and $1982 \mathrm{ml}$ after $24 \mathrm{~h}$ for $6 \mathrm{~g} \mathrm{RA}, 6 \mathrm{~g} \mathrm{RO}$ and no fat additive, respectively.
In conclusion, dietary RO depresses microbial activity more than its equivalent amount supplied directly into the batch cultures. The longterm effect of dietary RO does not seem to be entirely reproducible in the short term which suggests that the negative effect of RO is both progressive and selective. Comparative effects of RO and RA can be explained by a progressive release of fatty acids from RO in the medium, although no marked difference is observed in vivo (Doreau et al, 1989), probably due to a faster rate of lipolysis in the latter case.

Jouany JP, Thivend P (1986) Anim Feed Sci Technol 15, 215-229

Doreau M, Ferlay A, Elmeddah Y, Bauchart D (1989) Rev Franç Corps Gras 36, 271-278

Table I. Gas production from cellulose fermentation after $24 \mathrm{~h}$ of incubation ( $\mathrm{ml} / \mathrm{flask}$ ).

\begin{tabular}{cccc}
\hline $\begin{array}{c}\text { Supplementary } \\
R O(g)\end{array}$ & \multicolumn{2}{c}{ Diet } & $\begin{array}{c}\text { Overall mean } \\
(\mathrm{n}=8)\end{array}$ \\
\cline { 2 - 3 } & $\begin{array}{c}C \\
(\mathrm{n}=4)\end{array}$ & $\begin{array}{c}T \\
(\mathrm{n}=4)\end{array}$ & \\
& & & \\
\hline & 2153 & 1810 & $1982^{\mathrm{a}}$ \\
0 & 2013 & 1633 & $1824 \mathrm{~b}$ \\
6 & 1917 & 1623 & $1775^{\mathrm{bc}}$ \\
9 & 1900 & 1500 & $1700^{\mathrm{c}}$ \\
12 & & & \\
\hline
\end{tabular}

\footnotetext{
$\mathrm{a}, \mathrm{b}$ and $\mathrm{c}$ means in the same column with different superscripts differ $(p<0.001)$.
} 